\title{
NOTES ON THE SEVENTEENTH CENTURY PRINTING PRESS OF THE ENGLISH COLLEGE AT SAINT OMERS.
}

I. THE ST. OMERS ENGLISH BOOK-TRADE.

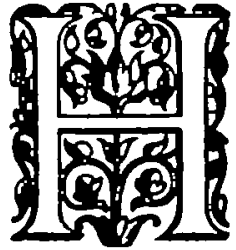

AVING recently had occasion to examine a large number of the English Catholic books published at St. Omers in the seventeenth century, I have arrived at certain conclusions about them which, I am advised, may be of use to others. Hence these notes. They will be confined, for the present, to books produced not later than 1642 .

I doubt whether it is at all realised nowadays how large a flood of these books was poured at that time from the presses at St. Omers. Appearing as they did for the most part without any indication on their title-pages of publisher or place of origin, one finds them often enough conjecturally ascribed in the British Museum catalogue and elsewhere to Douay or other continental centres of English Catholicism. Yet it is very doubtful if even Douay produced during those years as many English works of controversy and devotion as did St. Omers. Take John Gee's list of 'books printed and dispersed by the Priests and their agents in 


\section{PRESS OF THE ENGLISH COLLEGE}

this Kingdome within these two years last past or thereabouts'-one of the appendices to that interesting book of his, 'The Foot Out of the Snare,' printed in 1624 . Of some 150 titles here contained, over a third can be identified as those of books recently printed or reprinted at St. Omers. Or, if we take the works of English Jesuit writers in particular-and these form a very large proportion of the whole-it will be found that nearly all of them are from the same source.'

The reason is not far to seek. In the first place there was no more convenient starting-place for England than St. Omers; secondly, it was here that in 1592 Father Robert Persons established his famous English College ${ }^{2}$ and the Headquarters of the English Mission of the Society of Jesus.

\section{FRANCIS BELLET, 160I-1609.}

Francis Bellet was the first licensed printer at St. Omers. Up to 1601 he had served at Antwerp under Christopher Plantin and Moretus. The letter to the Privy Council at Brussels, dated 8th October, 1601 , in which the town authorities support his petition for a licence to set up a press is still preserved in the Brussels archives. It shows us that among the chief motives which attracted

I See in Foley's 'Records of the English Province S.J.,' vol. vi, pp. 521-32, a catalogue written in 1632 and now at Rome of 'English Writers S.J.' The list of writings is far from complete, but of some 112 English books enumerated, not less than 86 are stated to have been printed at St. Omers.

- For the history of this foundation, which after three migrations still survives as the Catholic College of Stonyhurst, see Gerard's 'History of Stonyhurst' (London, 1894). 
Bellet to St. Omers was the prospect of English trade there. ' $\mathrm{Y}$ a le collège des estudians anglois en grand nombre qu'il a pleu à sa majesté establir ... en ceste ville, et aultres colleges . ... ausquels le faict dudict Belet ... polra servir de beaucoup.'

By a piece of singular good fortune I have recently come across a copy of what is apparently the very first book produced by Bellet at his new press. It now belongs to the Stonyhurst Library, and lies before me as I write-a little vellum-bound duodecimo of 300 pages with the title: 'Epistres Dorees de S. Hierome, traduites de Latin en François. ... A S. Omer, chez François Bellet, Libraire \& Imprimeur juré, en la Tenne-rue, I602. Avec permission des superieurs.' The printer's dedication 'A Messeigneurs Messieurs les Mayeur et Eschevins de la Ville et Cité de S. Omer' is dated ' De S. Omer, ce dernier de Septembre, jour de S. Hierome, I602.' In this little book, he says he offers them his first fruits, 'Ayant esté admis le premier $\&$ attiré par vostre munificence liberale pour exercer en ceste ville l'art d'Imprimerie.'

Did Bellet print English books? I shall give later on my reasons for ascribing to him at least five important works of Father Persons himself during the years 1603 to 1607 . The prospects of his imprimerie must have begun to look rosy. Then comes a sudden disappointment. In 1609 (note the date) he leaves St. Omers for Ypres. And note the reason given. Someone had set up another

I De Lauwereyns 'L'Imprimerie à S. Omer' in 'Bulletin His13. 'tc ique de la Soc. des Antiq. de la Morinie,' vol. vij, p. 235 (1883). 


\section{PRESS OF THE ENGLISH COLLEGE}

press, which deprived him of the very trade on which he had counted most of all. ${ }^{3}$

\section{THE ENGLISH COLLEGE PRESS.}

There can be no possible doubt where and by whom that 'other press' was established. Father Henry More, the historian of the English Province S.J., tells us ${ }^{2}$ how Father Persons, soon after his confirmation by the General of the Society as Prefect of the Mission-this was in May, I606determined among other undertakings on a means to supply his countrymen with books of piety and devotion. To this end he set up at St. Omers a printing-press with all needful equipment, and placed it under the direction of a former secretary of his, a priest named John Wilson. Father More does not mention the date, and I have not found

I De Lauwereyns, 1.c.

- 'Historia Provinciae Anglicanae' (1660), lib. vi, p. 248. 'Postremo ut suae gentis hominibus in promptu esset librorum copia, tum . . ad alendam pietatem, tum ad haereticorum deliria detegenda, comparatum Audomari praelum cum omni necessario instrumento, commisit pio sacerdoti- Io. Wilsono, qui illi fuerat Romae Amanuensis, ut quos accepisset libros in lucem ederet. Cautumque fuit more provinciarum Societatis ut Censores constituerentur, qui scriptos primum viderent, suumque de iis iudicium Romam perscriberent, ut veritas argumentis solidis elucidaretur, abstineretur dicteriis, ac praecipue ab omni rerum publicarum inconsulta trabtatione, qua Regum magnatorumque animis exacerbatis religio detrimentum pateretur.' Then, after referring to Persons's 'Three Conversions' with the reply to Fox's 'Books of Martyrs' (though this, by the way, was not among the books published at the new press), he concludes, - Nullus fere abiit annus quo vel ab ipso conscriptus vel ab aliis de ipsius sententia liber aliquis non prodierit, magno catholicorum emolumento, heterodoxorum confusione et dolore.' 
any quite conclusive contemporary record. Internal evidence, however, as we shall see, puts it beyond doubt that the press was in full activity in 1608 and had produced its first book in 1607; which also perfectly agrees with what has been already recorded about Francis Bellet's departure.

The exact position of the 'print-house' is known to us from an old view of the College published about $1685^{\circ}$ It is shown there as a small three-

${ }^{1}$ An entry in the Annual Letters for St. Omers College, 1608, just falls short of conclusiveness through my not having been able to consult the original in the Brussels Archives. I can only quote from an imperfect transcript at Stonyhurst. This tells us how at Martinmas in that year the college was visited by the Bishop of the diocese. After dinner his Lordship insisted on being shown all round the premises ('omnia fere loca nostra videre voluit'). He highly approved of the site for the new church [this was between the college and the 'print-house'], 'sed prae omnibus dormiunculam quamdam habentem in se... cum omnibus aliis rebus ad illud spectantibus, quam nusquam ad illum finem accommodavimus, certe admirabatur.' The copyist has been unable to decipher the very words that most mattered! But, circumstances and context considered, surely the 'dormiuncula' (which, of course, should be 'domuncula') in question cannot be anything but our 'print-house,' and the missing words must be 'prelum ty pographicum' or the like. 'Nusquam' is probably an error for 'nuper.' Thus amended the passage will translate: 'But what he admired above all was a small house containing a printingpress with all its appliances, which (house) we have lately fitted up for this purpose.'

P.S. - A letter received after this paper had gone to press from a friend in Brussels, who has kindly consulted the original manuscript for me, confirms all the above conjectures:-'domunculam $\ldots$ habentem in se prelum ... quam nuper. ... Moreover, pulcherrime should be supplied after certe; - ' which we have lately fitted up, and that right nobly. . . That the adverb was justified, results prove. The reference to the manuscript is 'Archives du Royaume, Jesuitiques, Prov. Gallo-Belge, no. 32.'

'Reproduced in F. Gerard's 'Stonyhurst,' and (better) in 'Stonyhurst Magazine,' April, 1916 (vol, xiij, p. 1535). 
184 PRESS OF THE ENGLISH COLLEGE

storeyed house to the west of the college and church, fronting the Rue S. Bertin with one of those picturesque stepped gables which so often adorn the old houses of continental towns. The site would have been near where now stands the great gate of the Sous-Préfecture.

\section{JOHN WILSON, PRIEST.}

John Wilson, the director of the new press, deserves fuller treatment than he has hitherto received at the hands of the makers of dictionaries. He was born in Staffordshire about the year 1575; his parents being John and Alice Wilson, and the mother's maiden name Russell. He was a convert and in November, 1603 , was admitted as a student for the priesthood at the English College, Rome, being then 27 years of age. At Rome, as we have seen, he had been amanuensis or secretary to Father Persons, the Rector. Ordained priest in 1605 he started for the English mission, but cannot have seen much of it before being recalled to begin the work of his life in charge of the St. Omers College press.

There, though not a member of the society, he seems to have lived with the college community and to have taken a lively interest in the work of the place; to which indeed, being a man of some means, he was able to render valuable assistance. It was he who in the year 1621 added a new aisle to the college church, enlarged the sacristy, furnished the boys' sodality chapel, and enclosed 
and levelled a garden for the Fathers' recreations." It was he, too, who, a few years later, purchased for the college the 'villa' house at Blandyke, where the boys spent their weekly holiday in summer, while the interest he took in their studies is revealed to us in an exceedingly interesting document, which, having survived time and fire, confiscation and revolution, has somehow found its way to the British Museum.2 Here he is the 'magnus Maecenas,' the 'benevolus semper beneficusque Maecenas,' and lastly, in 1645 , the 'antiquus Maecenas,' to whose 'certissima liberalitas nullisque temporum exantlata injuriis munificentia' the boys were indebted for their annual prizes. After this last entry his name disappears. But in 1645 he was an old man of seventy, and probably died soon after.

Wilson's own contributions to literature do not

'See the 'Annual Letters,' St. Omers College, 1621, in Foley's 'Records,' vol. vij, P. 1158 .' The passage begins: 'R. D. Joannes Wilson, de quo saepius superioribus annis'; but unfortunately the Letters for several years are miscing, and there is no mention of Wilson in those that survive. The 1614 letter (Foley, p. 1156) is signed 'Io. Wilson' and was presumably written by him.

$\therefore$ Add. MS. 9354. The title on the cover, which bears front and back the college stamp, is: 'Registrum Audomarensis Anglorum Gymnasii." The title-page, written in bold Roman letters, runs: 'Aureus hic liber, Ingeniorum stimulus, industriae merces, dottorum custos nominum, a Rdo. Dna. Ioanne Wilsono, Audomarensis Anglorum Gymnasii magno Maecenate, annuac sure praemiorum distributioni adjunctus est; quo veluti traduce memoria propagetur eorum omnium qui doctrina caeteris antecellunt. Anno 1622.' The book contains the record of the 'six first' of each class in the monthly 'compositions' from 1622 to 1670 , with a few gaps. It also contains sundry notes which throw very interesting sidelights on the life of an English Catholic school beyond the seas in penal times. 


\section{PRESS OF THE ENGLISH COLLEGE}

seem to have been extensive. He was the author of the valuable 'English Martyrologe,' one of the books published in the first year of the new press. Besides this he translated several small books of controversy or religion, and his initials are attached to the dedications of many of his publications. But his chief title to fame will always be that for some forty years he presided over the St. Omers College Press and put forth several hundred volumes of orthodoxy for the edification of his fellowcountrymen.

\section{ENEMIES.}

$\mathrm{O}_{\mathrm{R}}$, in some cases, for their indignation. For of course the press soon became famous. The list of books which follows this article, incomplete as it is, shows how large a share it took in the religious controversies of James I's reign; and, in spite of the silence of their title-pages, those sturdy, wellprinted quartos-for Wilson's best printing was greatly superior to that of most other continental printers of English books; indeed, it will bear comparison with much of the very best contemporary London printing-could not long remain unrecognised. ${ }^{x}$

In 1626 a fierce attack was made on Wilson

In 1622 Henry Taylor, printer at Douay, writes to the Rector, warning him against a spy, Richard Floyd, who had lately furnished the king's agent, Turnbull, with 'un catalogue de tous les livres catholiques qui sont imprimes en anglais a $\mathrm{S}$. Omer ces 6 anntes passtes... et lui a terit qu'au colletge des Anglais ils ont un livre de corona regia pour imprimer en anglais mais dessous un autre titre "un fllau pour un Ecossais." De Lauwereyns, l.c. p. 237 . 
and his press by Lewis Owen. Owen was a man who, having lived for some time among the Jesuits at Valladolid ' as a curious observer,' says Anthony Wood, returned to put his observations at the disposal of the English Government. 'In the English College at Saint Omer,' he says,' 'the Jesuites have a printing Presse, to print such Popish Books and Seditious (yea, blasphemous) Pamphlets as are written by any English Jesuite. I may very well call some of them blasphemous Pamphlets, and among all the rest, that little Pamphlet, intituled "Prurit-Anus," which was written and twice printed in that College: but the copies for the most part taken, and at two severall times burned at Pauls-Cross after sermon time, about fourteene yeares agoe. The Authors, who were Wilson and the rest of the Jesuites there, (because it was stuffed with such horrible blasphemies) were ashamed to subscribe their own names thereunto, but borrowed a fained name of one Horatio Dolobella a Neapolitan.' Then after comparing the author to 'Julian the Apostata or Lucian the Atheist' - to the advantage of course of the latter-he continues:

Their Presse is worth unto them more than foure hundred pounds yearely. For they themselves are the Authors, Correctors, Composers, and Pressemen; in so much that it doth cost them nothing but.Paper and Inke, and these bookes they doe sell at an unreasonable rate: for they are not ashamed to sell a booke that containes not a quire of Paper, for five or sixe shillings; and to that purpose they have their Factors, and Brokers in

1 'Running Register,' London, 1626, p. 14. 


\section{PRESS OF THE ENGLISH COLLEGE}

London and all parts of England, to disperse and sell these Bookes and Pamphlets, and to transport the money unto them to Saint Omer.

Now I do not propose to enter into this last charge of extortionate prices, a cry which Owen has caught up from his friend John Gee: ${ }^{1}$ they both knew perfectly well what difficulties and perils attended the sale of Catholic books in England; but I cannot leave unnoticed the case of the 'blasphemous Pamphlet ' 'Prurit-anus.'

After much fruitless search, I discovered a copy of this book. ${ }^{2}$ It is a satire on the Puritan abuse of Scripture. It is not pleasant reading, and I have no wish to defend its author or authors, whoever they were-though perhaps I would not be quite as emphatic as Owen in their condemnation. I am convinced, too, that the book really was printed at St. Omers. But my point is, it was certainly not printed:at the English College Press. And further, if it was not printed there, it was certainly not the . work of 'Wilson and the rest of the Jesuites there'; for it is inconceivable that, having a private press of their own, as they had in 1609 , they would

1 'Foot out of the Snare,' 1624, p. 21, etc.

- The full title is: "Prurit-anus, vel Nec Omne, nec ex omni. Sive Apologia pro Puritanis \& Novatoribus universis. In qua et mores et opiniones Novorum Hominum nostri temporis auctoritate Scripturae affimantur et infirmantur. Ad Reformatos huius saeculi Fratres, Germanos, Gallos \& Britannos. Addita est etiam, per appendicem, similis Apologia pro Libro Ser. Iacobi Regis Magnae Britanniac nuperrime edito \& inscripto Praefatio Monitoria ad omnes Monarchas \& Principes Christianos etc. Per Horatium Dolobellam Neapolitanum.-Si male, nil peius; si bene, nil melius.-Lutetiae Britannorum, Apud Isacum Iacobi, M.DC.1x. $-4^{\circ}$, Pp. $40+$ Appendix 4 Pp.' 
have sent a book like this to be printed by an outsider. That it was not printed at the College Press will, I think, be evident to anyone who carefully examines its typography. At the end of this article I will enumerate and describe the characteristic features which distinguish the English College books from those printed. at St. Omers before (and some few after) I608, which I believe to have been the work of Francis Bellet. Suffice it to remark here that the typography of 'Pruritanus' attaches it unmistakably to the latter group.

\section{SOME OTHER PRINTERS.}

Ir would have been interesting to trace the vicissitudes of the press during the period under consideration, and to see how closely they reflect the political events of those eventful years; but this paper is already too long.

For the same reason I omit here all mention of another St. Omers press which was busy with English books during these years-that of Charles Boscard (1610-19) and his widow (1619-52), 'at the signe of the Name of Jesus.' He came from Douay and occupied, it would seem, the premises vacated by Bellet. Most of the 'St. Omers' books printed 'for' or 'by' John Heigham, were, I think, from this press. Two only will be found in the following list, under dates 1623 and 1625 , as having been apparently printed at the College Press.

The list also includes two books bearing the impress of George Seutin (1631). Seutin was 


\section{PRESS OF THE ENGLISH COLLEGE.}

one of Wilson's printers who had obtained a licence to print under his own name. He uses the College type and it is not quite clear what were his relations with the College Press.

Lastly, two small books are added, which appear to have been printed at the College Press in the years 1641 and 1642 . They are the only two I could discover for those years. From 1642 till long after the Revolution the press was silent.

In the next number of ' $T H E$ LIBRARY' I propose to complete this article with some notes on the typographical characteristics of the College Press, with a list of such of its books as I have personally identified.
C. A. Newdigate, S.J. 